\title{
Vertical climatic belts in the Tatra Mountains in the light of current climate change
}

\author{
Ewa Łupikasza $^{1}$ - Bartłomiej Szypuła ${ }^{2}$
}

Received: 17 December 2017 / Accepted: 18 April 2018 / Published online: 28 April 2018

(C) The Author(s) 2018

\begin{abstract}
The paper discusses temporal changes in the configuration of vertical climatic belts in the Tatra Mountains as a result of current climate change. Meteorological stations are scarce in the Tatra Mountains; therefore, we modelled decadal air temperatures using existing data from 20 meteorological stations and the relationship between air temperature and altitude. Air temperature was modelled separately for northern and southern slopes and for convex and concave landforms. Decadal air temperatures were additionally used to delineate five climatic belts previously distinguished by Hess on the basis of threshold values of annual air temperature. The spatial extent and location of the borderline isotherms of $6,4,2,0$, and $-2{ }^{\circ} \mathrm{C}$ for four decades, including $1951-$ 1960, 1981-1990, 1991-2000, and 2001-2010, were compared.

Significant warming in the Tatra Mountains, uniform in the vertical profile, started at the beginning of the 1980s and led to clear changes in the extent and location of the vertical climatic belts delineated on the basis of annual air temperature. The uphill shift of the borderline isotherms was more prominent on southern than on northern slopes. The highest rate of changes in the extent of the climatic belts was found above the isotherm of $0{ }^{\circ} \mathrm{C}$ (moderately cold and cold belts). The cold belt dramatically diminished in extent over the research period.
\end{abstract}

Keywords Carpathians · Vertical climatic belts $\cdot$ DEM

\section{Introduction}

Similar to latitudinal climatic zones, but distributed within short distances, vertical climatic belts (altitudinal zonation) constitute the most prominent feature of mountain areas from the viewpoint of climate studies (Beniston et al. 1997). Altitudinal zonation results from rapid changes in air temperature with increasing altitude, which impacts vegetation (Hess 1965; Niedźwiedź 1992) and many environmental processes (Beniston et al. 1997). Current climate change, identified as enormously accelerating global and regional warming (IPCC

Ewa Łupikasza

ewa.lupikasza@us.edu.pl

Bartłomiej Szypuła

bartlomiej.szypula@us.edu.pl

1 Department of Climatology, Faculty of Earth Sciences, University of Silesia in Katowice, ul. Będzińska 60, 41-200 Sosnowiec, Poland

2 Department of Geomorphology, Faculty of Earth Sciences, University of Silesia in Katowice, ul. Będzińska 60, 41-200 Sosnowiec, Poland
2013) which is proceeding particularly rapidly in European mountains (EEA 2009), may also manifest itself as a change in the configuration of altitudinal zonation. However, research on climate change and its impacts in mountainous areas is a challenging task, due to a scarcity of meteorological stations with long-term records of climate elements and to very complicated relief, which creates a mosaic of various microclimates. This also concerns the Tatra Mountains, the highest mountain range in Poland, which is characterised by very complicated relief which strongly influences air temperature distribution and other climate characteristics (Kożuchowski 1996). For example, the mean annual air temperature on the northern slopes ranges from about $5.8^{\circ} \mathrm{C}$ at altitudes of $600-650 \mathrm{~m}$ a.s.l. to $3.7^{\circ} \mathrm{C}$ at high elevations (Lomnicky štit, $2633 \mathrm{~m}$ a.s.l.) (Hess 1965; Konček 1974; Niedźwiedź 1992; Niedźwiedź et al. 2015). Studies on climate change in the Tatra Mountains are rare and usually based on data from only two meteorological stations, one located in the foothills of the Tatras in Zakopiańska Hollow (Zakopane station, $844 \mathrm{~m}$ a.s.l.) and the other on the peak of Kasprowy Wierch (1991 m a.s.l.). Increasing trends in annual and seasonal air temperature over the period 1951-2006 were identified at both stations 
(Żmudzka 2011). Progressive warming, particularly in the higher part of the Tatras, also took place between 1966 and 2006. Although insignificant, the rate of change in the annual air temperature on Kasprowy Wierch increased from $0.1 \mathrm{~K}$ per 10 years in 1951-2006 to $0.2 \mathrm{~K}$ per 10 years in $1966-2006$ (Żmudzka 2009). The trends for the periods updated to 2015 and 2016 were more rapid, reaching $0.2 \mathrm{~K}$ per 10 years for the period 1951-2015 (Lupikasza et al. 2016) and $0.3 \mathrm{~K}$ per 10 years for 1966-2016 (statistically significant at $\alpha \leq 0.001$, according to the present study). As the rate of warming at many high elevated sites is greater than the rate of global change, the impact of future climatic change may be stronger at high elevations (Beniston et al. 1997). Clear linear relationships between relief (altitude, aspect, and landform) and average annual air temperatures in the Tatra Mountains were recognised and quantified by Hess $(1965,1966,1968,1974)$ and then used to demarcate five vertical climatic belts.

This paper discusses the changes in location and extent of the altitudinal climatic belts in the Tatra Mountains in selected decades between 1951 and 2010. The paper consists of six sections, the second of which presents the study area and the classification of vertical climatic belts by Hess $(1965,1968)$. The data and methods used in the study are presented in Section 3. Because the configuration of vertical climatic belts depends on air temperature, Section 4 concerns temporal changes in decadal air temperature and constitutes a background for further analysis of changes in altitudinal zonation. The subsequent section, Section 5, includes an assessment of the relationship between annual air temperature and altitude, carried out separately for northern and southern slopes, for concave and convex landforms, and for each of four decades. This enabled us to create linear regression equations enabling calculation of the annual air temperature at any point in the vertical profile of the Tatra Mountains. Section 6 presents temporal changes in the location and extent of the vertical climatic belts; Section 7 includes a discussion of the possible consequences of shifts in altitudinal zonation; and Section 8 contains the conclusions.

\section{Study area and classification of vertical climatic zones in the Tatra Mountains}

Located in Central Europe $\left(49^{\circ} \mathrm{N}, 20^{\circ} \mathrm{E}\right)$ on the border of Poland and Slovakia (Fig. 1), the Tatra Mountains are the highest and the most rugged range of the Carpathians, occupying an area of $785 \mathrm{~km}^{2}$. The mean altitude is $1492 \mathrm{~m}$ a.s.l. and the highest peak, Gerlach, is $2655 \mathrm{~m}$ a.s.l. The typical alpine landscape of the Tatra Mountains, surrounded by wide basins, results in the most diversified climatic conditions in Central Europe. The complicated topography strongly influences the spatial and particularly the vertical distribution of air temperature, as is accurately reflected in clearly shaped vegetation belts (Hess 1965, 1968; Hess et al. 1975; Niedźwiedź
1992). Using average annual air temperature, Hess (1965, 1966, 1968) distinguished five vertical climatic belts, each representing a range of $2{ }^{\circ} \mathrm{C}$; their borders are delineated by threshold isotherms of $+6,+4,+2,0$, and $<-2{ }^{\circ} \mathrm{C}$, close to the highest peaks of the Tatra Mountains. Details concerning the vertical climatic belts in the Tatra Mountains are included in Table 1 and Fig. 2. Threshold isotherms are important for the environment. The $-2{ }^{\circ} \mathrm{C}$ isotherm determines the climatic snow line, while that of $0^{\circ} \mathrm{C}$ coincides with the upper limit of the subalpine belt. The upper timberline is delineated by an annual air temperature of $+2{ }^{\circ} \mathrm{C}$ and is equivalent to the location of the June isotherm of $+10^{\circ} \mathrm{C}$. The upper limit of mixed forest and agriculture is related to the annual $+4{ }^{\circ} \mathrm{C}$ isotherm.

Hess $(1965,1968)$ also found that altitude is the most prominent factor determining vertical changes in annual air temperature. Strong linear regression between these variables enables calculation of the annual air temperature at any point in the vertical profile of the Tatra Mountains. Hess $(1965,1968)$ constructed separate linear regression models for concave and convex landforms and for northern and southern slopes. These features (landforms and aspects) were recognised as additional factors influencing air temperature distribution. Hess (1965, 1974) observed that at the same elevations, concave forms (valleys, basin floors) and northern slopes are about $1{ }^{\circ} \mathrm{C}$ colder than convex forms (ridges, peaks) and southern slopes. Since vertical climatic belts are related to annual air temperature, climate changes will cause changes in their location (Kożuchowski 1996) and, probably, their extent. Based on an assumed increase of $2 \mathrm{~K}$ in the July air temperature (Olecka 1993), changes of ca $300 \mathrm{~m}$ in the locations of particular vertical climatic zones (between 300 and $360 \mathrm{~m}$, depending on zone) were assessed. The disappearance of the highest - the cold zone - is expected by the end of the twenty-first century (Kożuchowski 1996). Therefore, analysis of the current changes in altitudinal zonation is relevant and interesting.

\section{Environmental data and methods}

We used available climatological data on annual air temperature from 20 meteorological stations located in various parts of the Tatra Mountains and their surroundings (Fig. 1). The data represents four decades, including 1951-1960 and, subsequently, 1981-1990, 1991-2000, and the warmest period, 2001-2010, thus reflecting climate change in the study area. Data for decades between 1961 and 1980 were not available for us. We also used annual air temperatures for the period 1951-2016 from two synoptic stations which are still operating at present in Zakopane and on the peak of Kasprowy Wierch in order to discuss long-term changes in air temperature in the Tatra Mountains. The data was taken from the Meteorological Yearbooks published by the Institute of Meteorology and Water Management (IMGW 1959-1965) 


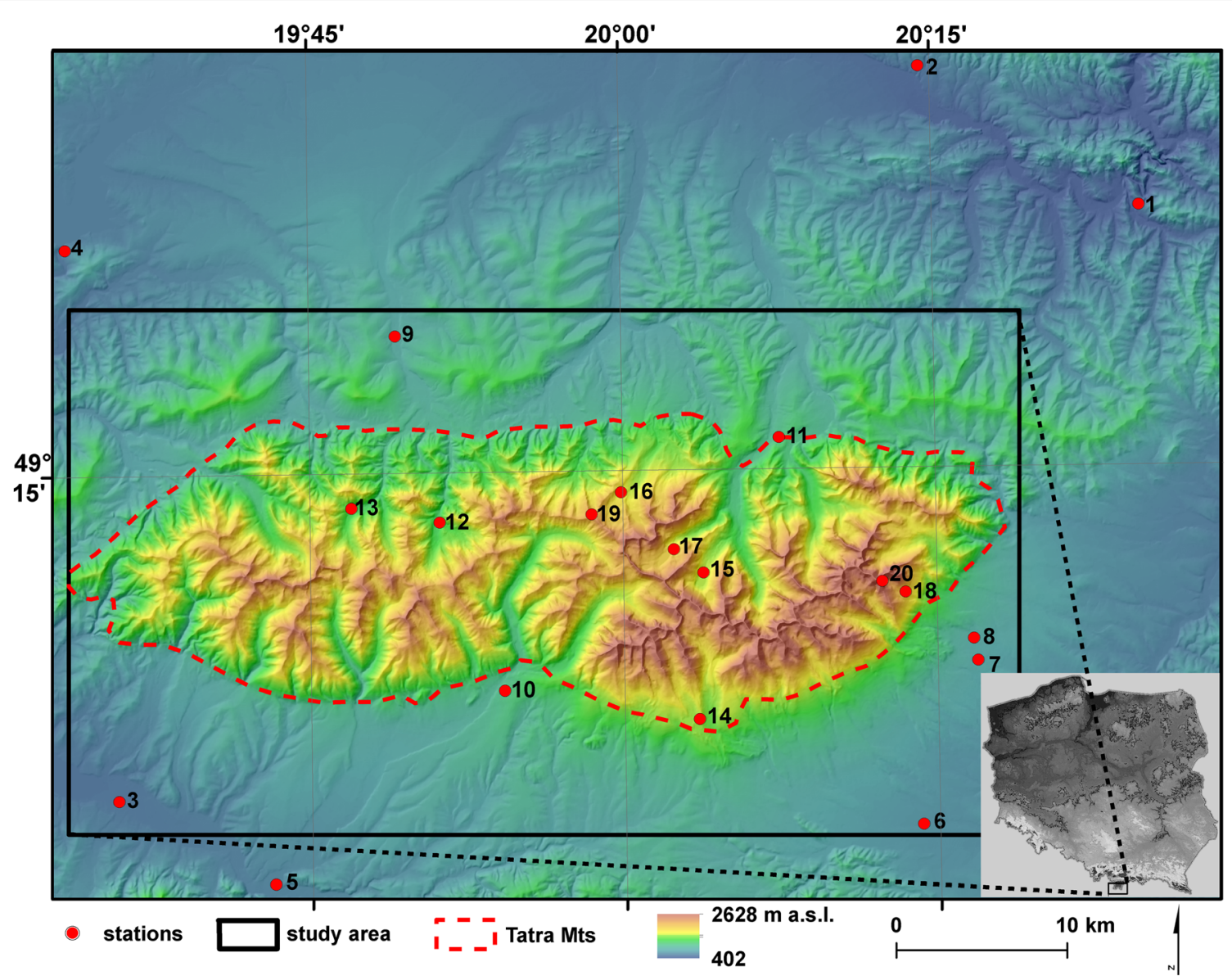

Fig. 1 Study area and location of meteorological stations in the Tatra Mountains, below, the station altitudes are given in the brackets: $1-$ Červený Kláštor (465 m), 2-Maniowy (520 m), 3-Liptovský Mikuláš (567 m), 4-Ústie n. priehradou (598 m), 5-Liptovský Hrádok (648 m), 6-Poprad-Tatry (694 m), 7-Stará Lesná (807 m), 8-Tatranská Lomnica $(827$ m), 9-Witów (835 m), 10-Podbanské

and from the OGIMET database (Valor 2017). The station data and the Hess method (1968) were used to reconstruct linear regression equations separately for four decades (1951-1960, 1981-1990, 1991-2000, 2001-2010), which were used in turn to calculate mean annual air temperatures
(972 m), 11-Tatranská Javorina (1030 m), 12-Hala Ornak (1109), 13-Polana Chochołowska (1145 m), 14-Štrbské Pleso (1354 m), 15-Morskie Oko (1400), 16-Hala Gąsienicowa (1523 m), 17Dolina 5 Stawów (1674 m), 18-Skalnaté Pleso (1778 m), 19Kasprowy Wierch (1991 m), and 20 - Lomnicky Štit (2635 m).

at each of a dense set of points representing the diversity of the topography of the Tatra Mountains (Fig. 1). The modelled decadal air temperature data was additionally used to identify the location of the vertical climatic belts and to assess their temporal changes.
Table 1 Vertical climatic belts in the Tatra Mountains after Hess (1965)

\begin{tabular}{|c|c|c|c|}
\hline \multirow[t]{2}{*}{ Vertical climatic belt } & \multirow[t]{2}{*}{ Mean annual air temperature } & \multicolumn{2}{|l|}{ Altitude in $\mathrm{m}$} \\
\hline & & Northern slopes & Southern slopes \\
\hline Cold & Below $-2{ }^{\circ} \mathrm{C}$ & Above 2200 & Above 2350 \\
\hline \multicolumn{4}{|c|}{ Climatic snow line, lower limit of seminival belt } \\
\hline Moderately cold & -2 to $0{ }^{\circ} \mathrm{C}$ & $2200-1850$ & $2350-2050$ \\
\hline \multicolumn{4}{|c|}{ Upper limit of subalpine belt with Pinus Mughus } \\
\hline Very cool & 0 to $+2{ }^{\circ} \mathrm{C}$ & $1850-1550$ & $2050-1650$ \\
\hline \multicolumn{4}{|c|}{ Upper tree line (timberline) } \\
\hline Cool & +2 to $+4{ }^{\circ} \mathrm{C}$ & $1550-1150$ & $1650-1200$ \\
\hline \multicolumn{4}{|c|}{ Upper limit of agriculture and mixed forest } \\
\hline Moderately cool & +4 to $+6^{\circ} \mathrm{C}$ & $1150-650$ & $1200-700$ \\
\hline
\end{tabular}


Fig. 2 Diagram for vertical climatic zones in the Tatra Mountains after Hess (1966)

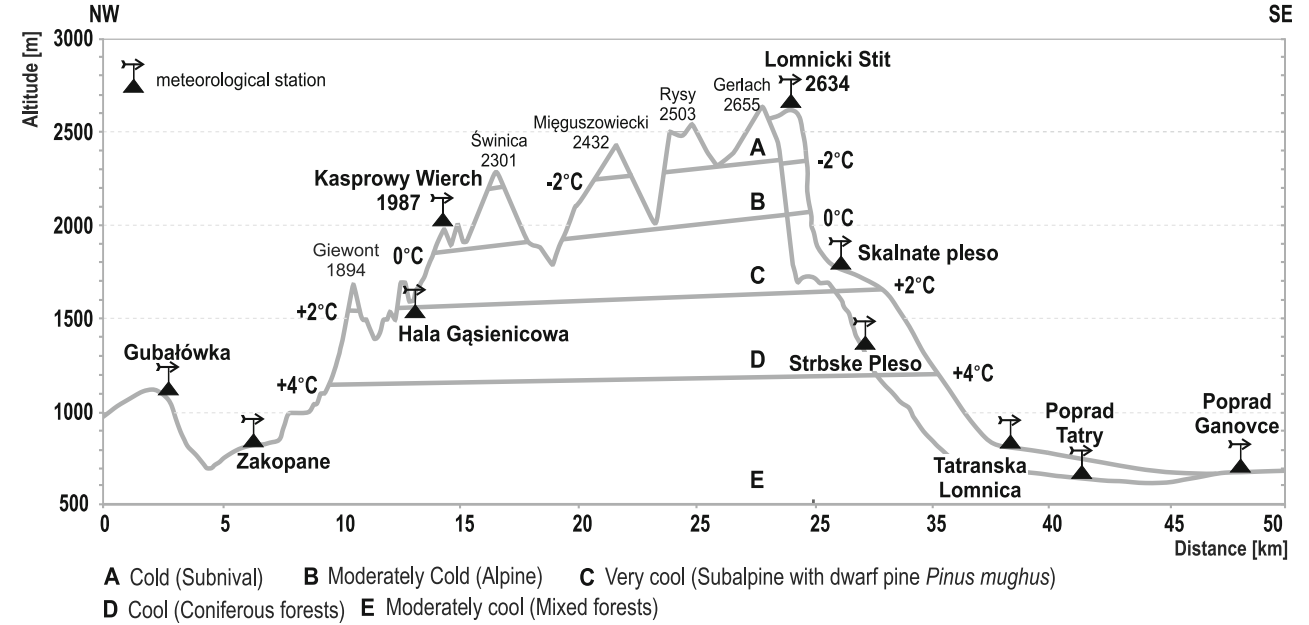

To obtain denser information on decadal air temperature, we generated a regular network of points $(500 \mathrm{~m} \times$ $500 \mathrm{~m}$ ) covering the research area. Then, on the basis of a digital elevation model (DEM) (NMT 2014), we selected 1896 points with clear southern (azimuth $135^{\circ}-225^{\circ}$ ) or northern (azimuth $315^{\circ}-360^{\circ}$ and $0^{\circ}-45^{\circ}$ ) aspects, located within clearly shaped concave (valleys, basins, topographic lows) or convex (ridges, peaks, crests) landforms (Fig. 3). The average density of the selected points is 1.1 pts. per $\mathrm{km}^{2}$ for the entire study area and 1.8 pts. per $\mathrm{km}^{2}$ for the Tatra Mountains. The DEM covers about $1712 \mathrm{~km}^{2}$ (Fig. 1). Where necessary, the network was modified by adding new points or by relocating the existing points to represent a characteristic feature of the topography. ArcGIS software (Esri 2016) was used for interpolation and planimetric calculations.
Mean absolute error (MAE) and root mean square error (RMSE) were used to assess the accuracy of the linear regression models for mean annual air temperature, with altitude as a predictor. MAE, which measures the average magnitude of errors in a set of predictions without considering their direction, is the average of the absolute differences between a prediction $(\hat{y} i)$ and actual observation $(y i)$ at $n$ stations, where all individual differences have equal weight (Eq. 1).

$\mathrm{MAE}=\frac{1}{n} \sum_{i=1}^{n}|y i-\hat{y} i|$

RMSE, a quadratic scoring rule that also measures the average magnitude of error, is the square root of the
Fig. 3 Points selected to model mean annual air temperature based on altitude for south (red dots) and north slopes (blue dots) and convex (orange dots) and concave (black dots) land forms and used to delineate the borders between vertical climatic belts

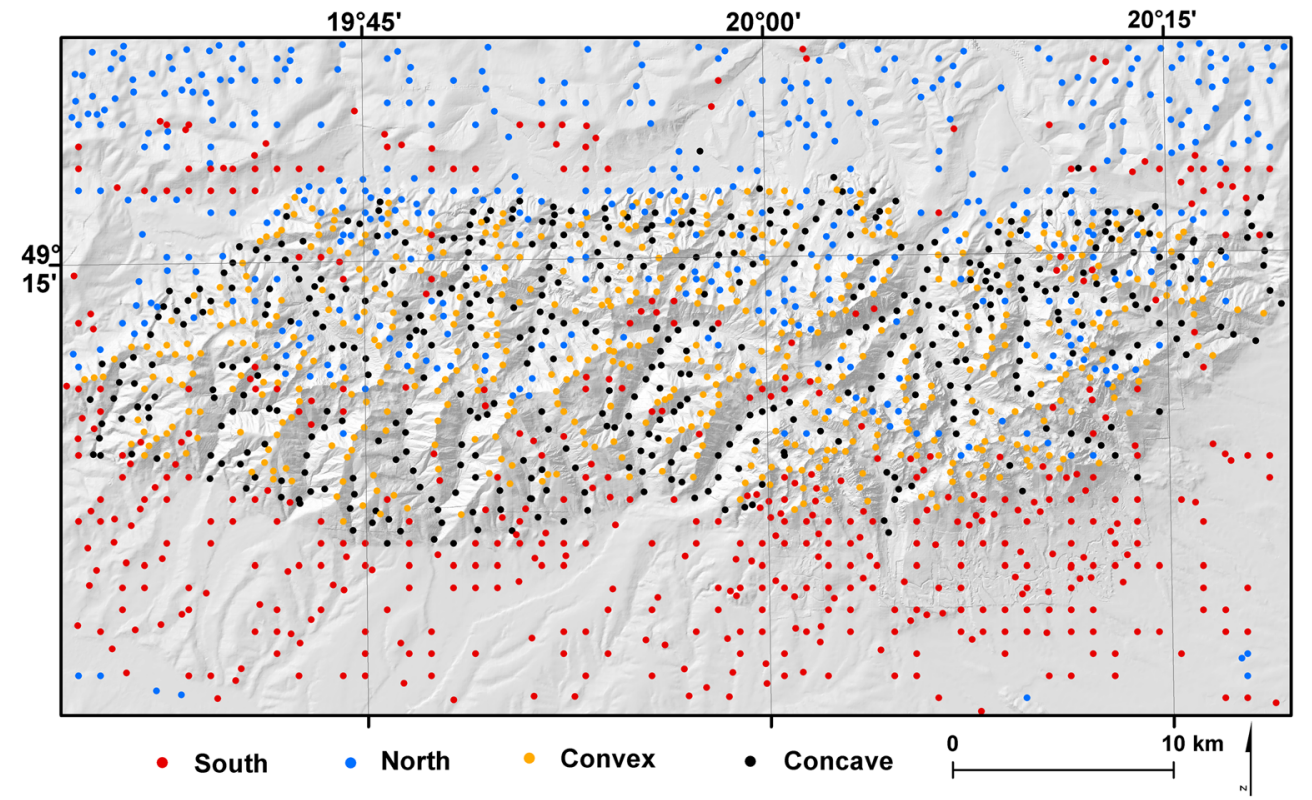


average of squared differences between a prediction $(\hat{y} i)$ and actual observation (yi) (Eq. 2) at $n$ stations.

$\mathrm{RMSE}=\sqrt{\frac{1}{n-2} \sum_{i=1}^{n}|y i-\hat{y} i|}$

RMSE is always larger than or equal to MAE. The greater the difference between errors, the greater the variability in individual errors in the sample.

\section{Changes in mean decadal air temperature in station data}

Annual air temperature was recognised as a complex characteristic of the thermal conditions responsible for, inter alia, the distribution of vertical climatic belts (Hess 1965). Therefore, we begin by presenting decadal changes in annual air temperature using data from 15 meteorological stations for each of the four decades being considered. Detailed changes are reviewed based on data covering the period 1951-2016 from two synoptic stations operating currently in the foothills of the Tatra Mountains (Zakopane, $857 \mathrm{~m}$ a.s.l.) and on the peak of Kasprowy Wierch (high mountain station, 1991 m a.s.l.). The locations of four of the stations (Štrbské Pleso, Liptovský Mikuláś, Tatranská Lomnica, and Tatranská Javorina) were shifted during the research period but revision of metadata and personal information from the Slovak Hydrometeorological Institute indicated no serious inhomogeneity in decadal averages of annual air temperature.

The average annual air temperature calculated from decadal averages varied from $7.1^{\circ} \mathrm{C}$ (Liptovský Mikuláš, $567 \mathrm{~m}$ ) to $-3.5^{\circ} \mathrm{C}$ (Lomnicky štit, $2635 \mathrm{~m}$ ). At most of the stations, the first decade (1951-1960) was the coolest, but at every station, the highest annual temperatures were those for the last decade, which indicates gradual warming (Fig. 4). The difference in average air temperature between 1951-1960 and 2001-2010 ranged from 0.2 to $1.2 \mathrm{~K}$, depending on the station. Both the smallest and the largest differences were associated with altitudes up to ca $1450 \mathrm{~m}$ a.s.l. Above $1500 \mathrm{~m}$ a.s.l., the rate of warming varied between 0.8 and $1.1 \mathrm{~K}$. Non-gradual changes in air temperature at some stations show that decadal time resolution may still reflect variability and, in some cases, might involve too brief a period to visualise general trends in climate elements (Fig. 4).

The horizontal dashed line in Fig. 4 (left-hand graph) represents the boundaries between vertical climatic belts in the Tatra Mountains (from $+6{ }^{\circ} \mathrm{C}$ to $<-2{ }^{\circ} \mathrm{C}$ ). At some stations located in the vicinity of the boundaries, air temperatures crossed the threshold values, which is evidence for potential shifts in the locations of the vertical climatic belts.

Linear trends calculated for the entire research period indicate statistically significant warming at a rate of $0.3 \mathrm{~K}$ per decade in Zakopane and $0.2 \mathrm{~K}$ per decade on Kasprowy Wierch. In fact, two periods with different trend magnitudes (Zakopane) or directions (Kasprowy Wierch), from 1951 to 1980 and from 1980 to 2016, are distinctly visible within the long-term course of annual air temperature (Fig. 5). In the 30year period between 1951 and 1980, Zakopane saw mainly fluctuations with no trends, while Kasprowy Wierch experienced decreases, though insignificant, in annual air temperature at the rate of $-0.1 \mathrm{~K}$ per decade. These differences in the course of air temperature at the stations might have been related to highest frequency of cyclonic weather between 1965 and 1980 which possibly influenced air temperature in the highest parts of the Tatra Mountains. Urbanisation in the city
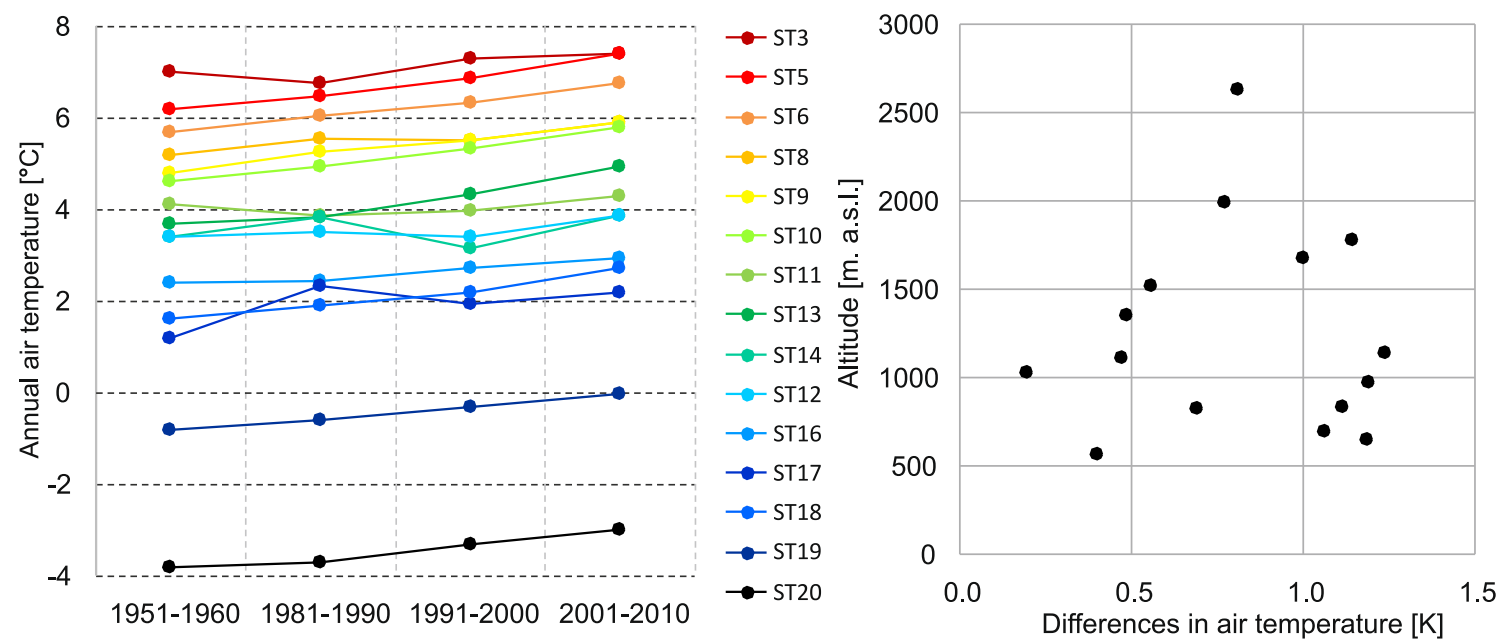

Fig. 4 Average annual air temperatures for selected decades at selected meteorological stations located in the Tatra Mountains and its vicinity, the numbering of stations is compatible with Tables 2 and 4. ST3-Liptovský Mikuláš, ST5-Liptovský Hrádok, ST6 - Poprad-Tatry, ST8-Tatranská

Lomnica, ST9-Witów, ST10—Podbanské, ST11—Tatranská Javorina, ST13-Polana Chochołowska, ST14-Štrbské Pleso, ST12-Hala Ornak, ST16-Hala Gąsienicowa, ST17-Dolina 5 Stawów, ST18Skalnaté Pleso, ST19-Kasprowy Wierch, and ST20 - Lomnicky Štit 
Fig. 5 Long-term course and trends in annual air temperature in Zakopane (upper line) and Kasprowy Wierch (lower line), trends are calculated for the periods 1951-2016 (read line), 1951-1980, and 1980-2016; $p$ the level of statistical significance

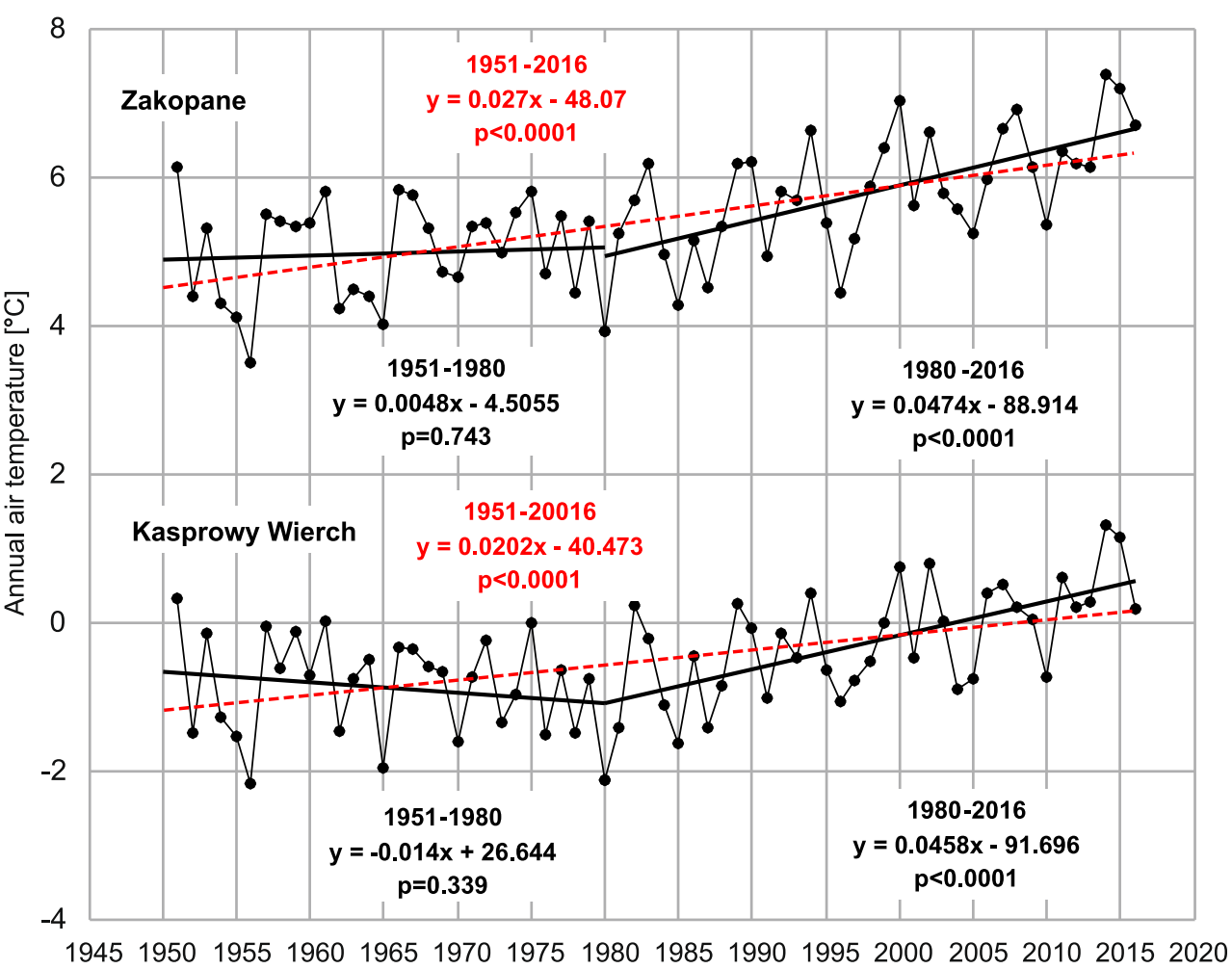

of Zakopane was also supposed to play some role; however, this needs further research. Thus, the earliest of the analysed decades (1951-1960) represents a period of relatively stable thermal conditions. Rapid warming of a rate of $0.55{ }^{\circ} \mathrm{C}$ per decade in the Tatra Mountains began at the beginning of the 1980 s and has continued to date. Crucial changes with respect to vertical climatic belts in Zakopane and Kasprowy Wierch may have taken place between 1990 and 2005. Prior to 1990, the average annual air temperature barely exceeded $+6{ }^{\circ} \mathrm{C}$ in Zakopane and $0^{\circ} \mathrm{C}$ on Kasprowy Wierch. After 2005, the only annual air temperatures below $+6^{\circ} \mathrm{C}$ or $0{ }^{\circ} \mathrm{C}$, respectively, occurred in 2010. At both stations, the lowest annual air temperature occurred in 1956 (Kasprowy Wierch $-2.2{ }^{\circ} \mathrm{C}$, Zakopane $+3.5^{\circ} \mathrm{C}$ ), the highest in 2014 (Kasprowy Wierch $+1.3^{\circ} \mathrm{C}$, Zakopane $+7.2^{\circ} \mathrm{C}$ ). The range of variability reached $3.5^{\circ} \mathrm{C}$ at Kasprowy Wierch and $3.7^{\circ} \mathrm{C}$ at Zakopane. The distribution of vertical climatic belts for the last of the analysed decades results from current climate change. This pattern of changes might be representative of the greater part of the Tatra Mountains area, as the long-term series of air temperature are significantly correlated between one station and another. Most of the correlation coefficients calculated for the period 1981-2010 exceeded 0.8 (not shown).

However, some local differences are possible, due to the great variability of local environmental conditions which may blur general trends. For example, at the Kasprowy Wierch station, the period between ca 1975 and 1978 was cooler than previous years, which was not the case in Zakopane. Local variations in the course of annual temperature are evidenced by the nongradual course of decadal averages at some stations including Tatranská Lomnica, Hala Ornak, Štrbské Pleso, and Dolina Pięciu Stawów, where the averages for 1991-2000 were lower than for the 1981-1990 period (Fig. 4). Although the location of Štrbské Pleso station has been shifted during the research period (from 1330 to $1353 \mathrm{~m}$ of altitude in 1961, by $1 \mathrm{~m}$ higher in 1992 and from 1354 to $1322 \mathrm{~m}$ of altitude in 2005), any inhomogeneity was recognised in 10-year means of annual air temperature (personal information for Pavel Št'astnỳ, the Slovak Hydrometeorological Institute). Therefore, it is reasonable to assume that the relocation of Tatranská Lomnica station by only $7 \mathrm{~m}$ of altitude in 1993 also did not significantly influence decadal annual air temperature.

\section{Linear relationships between relief, aspect, and annual air temperature in the Tatra Mountains}

Unfortunately, the number of stations operating within the Tatra Mountains has decreased since Hess's day; therefore, in order to calculate the linear regression equations, we used data from 20 meteorological stations. The stations were divided into four groups, depending on the aspects (northern or southern slopes) and landforms (concave or convex) identified based on DEM and on knowledge acquired during fieldwork in the Tatra Mountains (Table 2). 
Table 2 List of stations used to calculated linear regression equations describing relations between altitude and decadal averages of annual air temperature for decades: 1951-1960 (A), 1981-1990 (B), 1991-2000 (C), 2001-2010 (D)

\begin{tabular}{|c|c|c|c|c|c|c|c|c|c|c|c|c|c|c|c|c|c|c|}
\hline \multirow[t]{2}{*}{ Lp. } & \multirow[t]{2}{*}{ Station } & \multirow[t]{2}{*}{ H [m a.s.l.] } & \multicolumn{4}{|c|}{ Northern aspect } & \multicolumn{4}{|c|}{ Southern aspect } & \multicolumn{4}{|c|}{ Concave relief } & \multicolumn{4}{|c|}{ Convex relief } \\
\hline & & & A & B & $\mathrm{C}$ & $\mathrm{D}$ & A & B & $\mathrm{C}$ & $\mathrm{D}$ & A & B & $\mathrm{C}$ & $\mathrm{D}$ & A & $\mathrm{B}$ & $\mathrm{C}$ & $\mathrm{D}$ \\
\hline 1 & Červený Kláštor & 465 & & + & + & + & & & & & & & & & & & & \\
\hline 2 & Maniowy & 520 & + & & & & & & & & & & & & & & & \\
\hline 3 & Liptovský Mikuláš & 567 & & & & & + & + & + & + & & & & & & & & \\
\hline 4 & Ústie n. priehradou & 598 & + & & & & & & & & & & & & & & & \\
\hline 5 & Liptovský Hrádok & 648 & & & & & + & + & + & + & + & + & + & + & & & & \\
\hline 6 & Poprad-Tatry & 694 & & & & & & & & & + & + & + & + & & & & \\
\hline 7 & Stará Lesná & 807 & & & & & & + & + & + & & & & & & + & + & + \\
\hline 8 & Tatranská Lomnica & 827 & & & & & & & & & + & + & + & + & & & & \\
\hline 9 & Witów & 835 & + & + & + & + & & & & & & & & & & & & \\
\hline 10 & Podbanské & 972 & & & & & + & + & + & + & & & & & + & + & + & + \\
\hline 11 & Tatranská Javorina & 1030 & + & + & + & + & & & & & + & + & + & + & & & & \\
\hline 12 & Hala Ornak & 1109 & + & + & + & + & & & & & + & + & + & + & & & & \\
\hline 13 & P. Chochołowska & 1145 & & & & & & & + & + & & & & & & & & \\
\hline 14 & Štrbské Pleso & 1354 & & & & & + & + & + & + & & & & & + & + & + & + \\
\hline 15 & Morskie Oko & 1400 & & & & & + & & & & & & & & & & & \\
\hline 16 & Hala Gąsienicowa & 1523 & & & & & & & & & & & & & + & + & + & + \\
\hline 17 & Dolina 5 Stawów & 1674 & & & & & + & + & + & + & & & & & + & + & + & + \\
\hline 18 & Skalnaté Pleso & 1778 & & & & & + & + & + & + & & & & & & & & \\
\hline 19 & Kasprowy Wierch & 1991 & & & & & & & & & & & & & + & + & + & + \\
\hline 20 & Lomnicky Štit & 2635 & & & & & & & & & & & & & + & + & + & + \\
\hline
\end{tabular}

Depending on the decade, we selected between 4 and 5 stations located on the northern slopes, between 7 and 9 stations located on the southern slopes, 6 stations located in concave landforms, and 6 or 7 stations located in convex landforms. The altitude of the stations ranged from 465 to $2635 \mathrm{~m}$ a.s.l. Hess (1968) used stations located between 600 and $1600 \mathrm{~m}$ a.s.l. Some stations were rated according to both aspect and landform. Linear regressions between decadal air temperature and altitude depending on landform and aspect for the analysed decades are shown in Figs. 6 and 7.

The regression equations describing the relationship between variables and coefficients of determination indicating the percentage of vertical changes in annual air temperature explained by altitude are included in Table 3. Table 3 also contains decadal mean annual air temperatures calculated from regression models for the arbitrarily selected altitudes of 1000 and $1500 \mathrm{~m}$ a.s.l. The model for concave forms was used for altitudes $\leq 1600 \mathrm{~m}$ a.s.l. In every decade, mean annual air temperature was higher on southern slopes than on northern slopes by an average of $0.9 \mathrm{~K}$ at 1000 and $0.8 \mathrm{~K}$ at $1500 \mathrm{~m}$ a.s.l. The difference in air temperature between $\mathrm{N}$ and $\mathrm{S}$ slopes increased in subsequent decades; for example, at the altitude of $1000 \mathrm{~m}$, it rose from $0.6 \mathrm{~K}$ in 19511960 to $1.0 \mathrm{~K}$ in 2001-2010, while at $1500 \mathrm{~m}$, it increased from $0.4 \mathrm{~K}$ in $1951-1960$ to $0.9 \mathrm{~K}$ in 2001-2010. An increase in decadal air temperatures between 1951-1960 and 2001-2010 on northern slopes proceeded at a lesser rate $(0.4 \mathrm{~K}$ at 1000 and $0.5 \mathrm{~K}$ at $1500 \mathrm{~m})$ than on southern slopes $(0.8 \mathrm{~K}$ at 1000 and 0.1 at $1500 \mathrm{~m}$ ). The differences between concave and convex landforms were even greater than those between slopes of opposite aspect. The annual air temperature for concave landforms was higher on average by $0.7 \mathrm{~K}$ at 1000 and by $1.5 \mathrm{~K}$ at $1500 \mathrm{~m}$ a.s.l. These differences grew in the subsequent decades, particularly in the upper part of the mountains (at $1500 \mathrm{~m}$ ), reaching $0.7 \mathrm{~K}$ in $1951-1960,1.5 \mathrm{~K}$ in $1981-1990,1.9 \mathrm{~K}$ in 1991-2001, and 1.9 $\mathrm{K}$ in 2001-2010.

This clear increase in the differences between the two kinds of landforms is due to various temporal tendencies in modelled decadal air temperatures (T1500 m, Table 3), increasing for convex but mainly decreasing for concave landforms. The only positive tendency for concave landforms occurred between 1991-2000 and 2001-2010. Coefficients of determination in most cases exceed 0.90 and, when the northern slopes are excluded, 0.97, which means that altitude explains more than $97 \%$ of changes in decadal air temperatures in the vertical profile of the Tatra Mountains. The smallest regressions were found for the northern slopes, where altitude explains from 88 to $94 \%$ of vertical changes in decadal air temperatures (Table 3 ).

In order to validate the linear regression models, we first calculated mean decadal air temperatures for stations using the linear regression equations, followed by the differences 

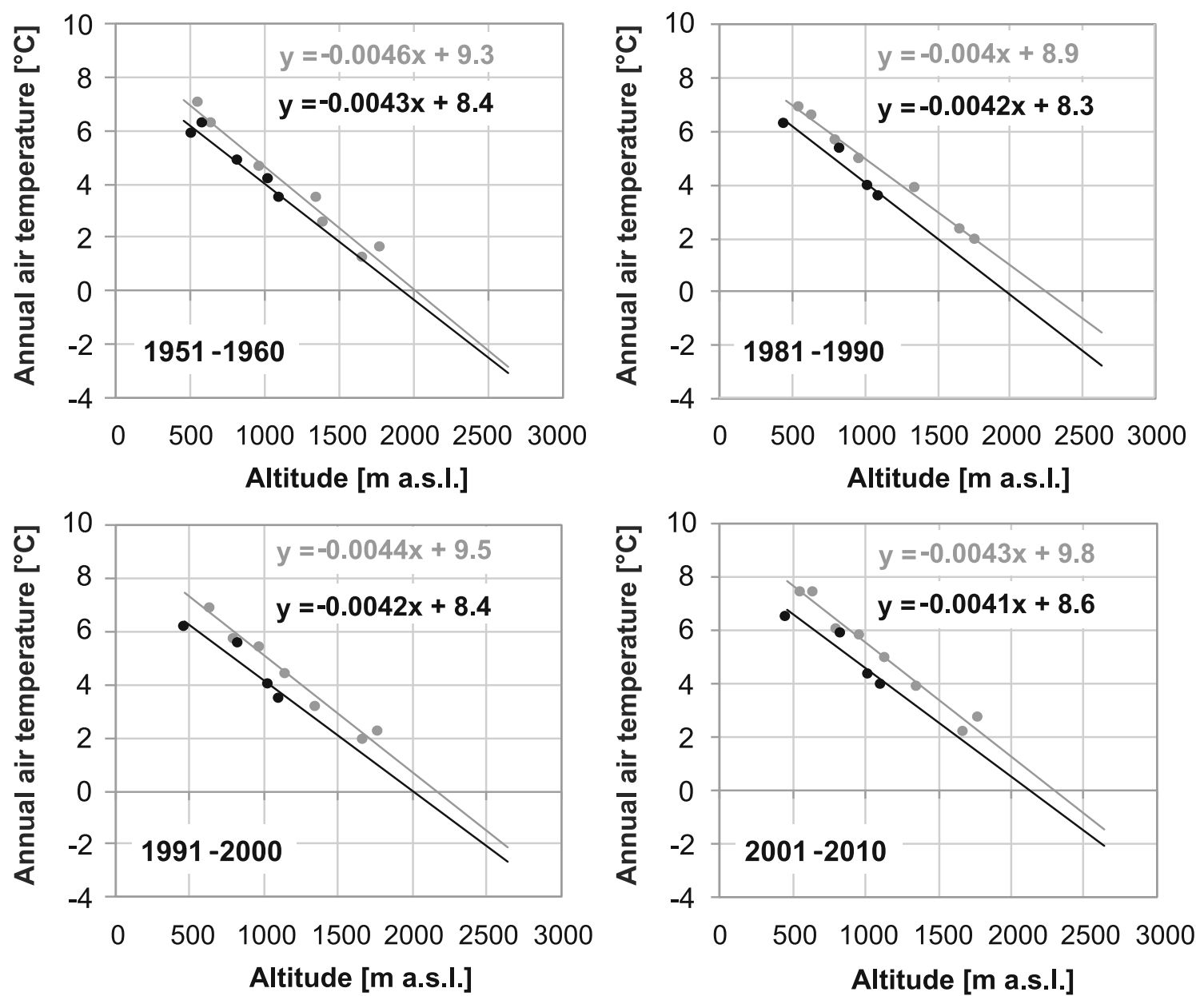

Fig. 6 Linear regression between altitudes and decadal averages of annual air temperature for northern (black) and southern (grey) aspects, decades: 1951-1960, 1981-1990, 1991-2000, 2001-2010

between station and modelled data. Model accuracy was also assessed with MAE and RMSE, which are in common use. The resulting differences are included in Table 4; MAE and RMSE are presented in Table 5.

The smallest errors are those for northern slopes and concave landforms, which means that the correlation between annual air temperature and altitude is the strongest for northern aspects and in topographic lows. The greatest errors, and thus the weakest correlations between air temperature and altitude, are found for convex landforms. The variability in single errors increases on northern slopes and concave landforms, as evidenced by the growing differences between MAE and RMSE (Table 4).

\section{Temporal changes in the vertical climatic belts}

\subsection{Temporal changes in the extent of the vertical climatic belts in the Tatra Mountains}

Decadal air temperatures modelled for the dense set of points were used to assess the location and extent of vertical climatic belts for every decade. Individual climatic belts are delineated by the isotherms $+6,+4,+2,0$, and $-2{ }^{\circ} \mathrm{C}$ (Hess 1965). The distribution of vertical climatic belts in the earliest (19511960) and in the latest (2001-2010) of the analysed decades is shown in Fig. 8. Detailed information on changes in the extent of particular climatic belts in subsequent decades is presented in Table 6, which includes the planar areas of each belt in both square kilometres and percentages. The location and extent of the belts have clearly changed over the decades. These changes are sensitive to changes in average decadal air temperature, and thus not uniform within the vertical profile of the Tatra Mountains. The lowest part of the research area, with decadal air temperatures higher than $+6{ }^{\circ} \mathrm{C}$, expanded substantially throughout the period, until finally, in 2001-2010, its area was more than $17 \%$ greater than in 1951-1960. As a result, the extent of the moderately cool belt was significantly reduced in the southern part of the area. In fact, each of the belts with decadal air temperatures $<+4{ }^{\circ} \mathrm{C}$ was smaller than it had been in the previous decade. However, the differences in the extent of climatic belts between the relatively cool decade of 1981-1990 and the two adjoining decades of 1951-1960 and 1991-2001 vary between positive and negative values for 

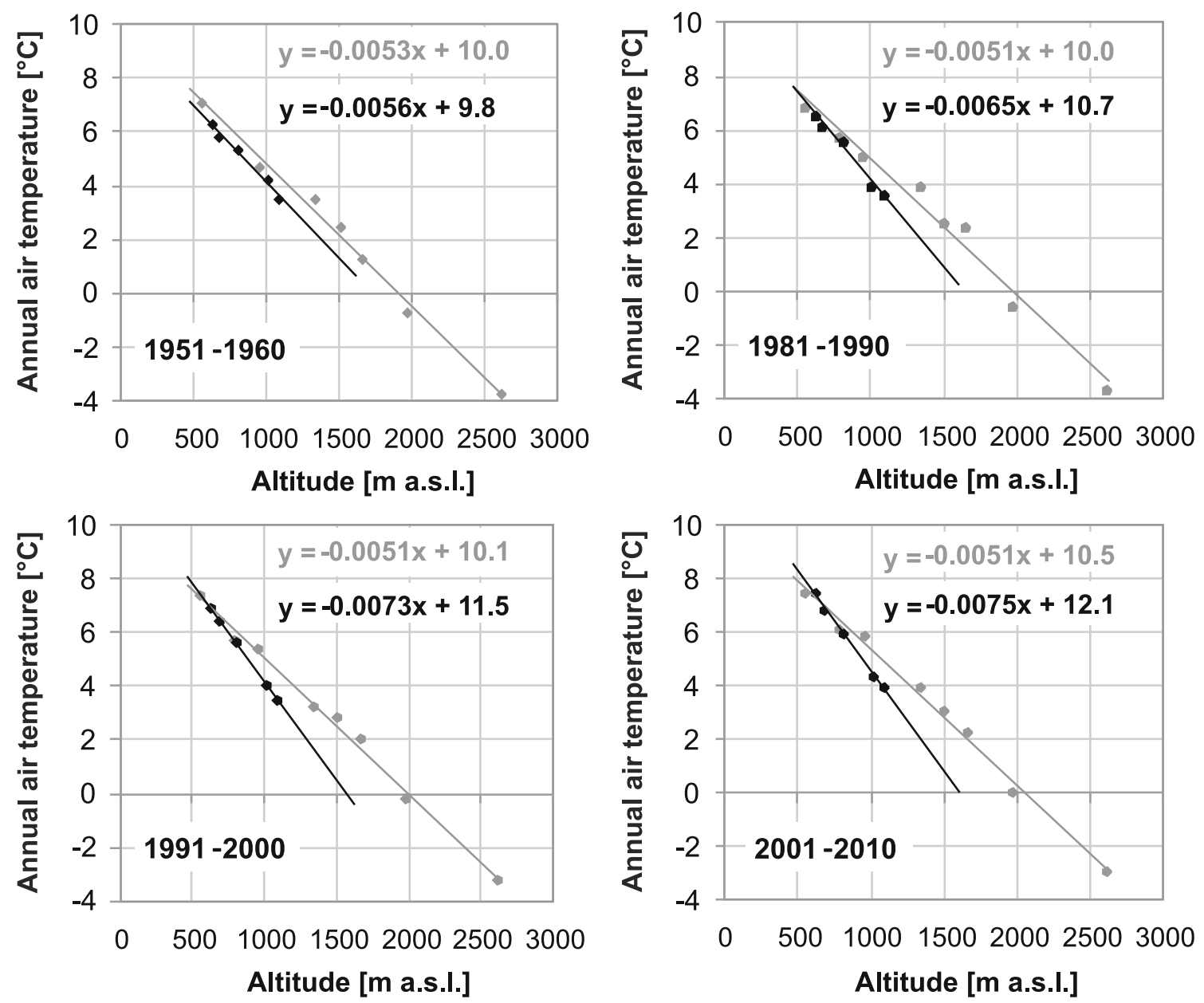

Fig. 7 Linear regression between altitudes and decadal average of annual air temperature for concave (black) and convex (grey) relief, decades: 19511960, 1981-1990, 1991-2000, 2001-2010

moderately cold, very cool, and moderately cool belts. A continuous and consequent decrease, albeit one occurring at different rates, was noted in the area of the cold and cool belts, with the exception occurring between 1981-1990 and 19912000 in the highest cold belt (Table 6). Over the past decade, the cold belt with air temperatures below $-2{ }^{\circ} \mathrm{C}$ virtually disappeared, as it covered barely noticeable areas $\left(0.2 \mathrm{~km}^{2}\right)$ located among the highest peaks of the High Tatra Mountains (>2450 $\mathrm{m}$ a.s.1.). The area occupied by the moderately cold belt in 2001-2010 was also much smaller than in 1951-1960, particularly in the western Tatra Mountains (Fig. 8).

It is also informative to express the areas of the belts during the past decade (2001-2010) as a percentage of their areas in the earliest decade. The area of the belt with annual air temperature $>6{ }^{\circ} \mathrm{C}$ in the last decade was more than three times greater than in 1951-1960, while the moderately cool and cool belts in 2001-2010 constituted about 83 and $80 \%$ of the corresponding areas in 1951-1960. The smallest decrease (by $10 \%$ ) occurred in the very cool belt. Prominent changes took place above the isotherm of $0{ }^{\circ} \mathrm{C}$, where, in the last decade, the moderately cold belt occupied $62 \%$ of its $1951-$
1960 area. However, the most dramatic changes concern the highest and smallest belt, which diminished by $94 \%$ over the past decade.

\subsection{Temporal changes in the altitude of the vertical climatic belts in the Tatra Mountains}

Changes in any environmental conditions, including climate, can be observed first within boundary areas, which are transitional zones rather than lines; these areas are the most prone to changes. Thus, the response of the climatic belts to changes in air temperature is also clearly reflected in the temporal changes in altitudes of the borderline isotherms presented in Fig. 9 and quantified in Table 7. The mean, maximum, and minimum altitudes for the borderline isotherms, depending on aspect (northern and southern), are presented in Table 7. We used only those parts of slopes with aspects between $315^{\circ}$ $360^{\circ}$ and $0^{\circ}-45^{\circ}$ for northern slopes and between $135^{\circ}$ and $225^{\circ}$ for southern slopes. In the case of most isotherms, excluding the highest $\left(-2^{\circ} \mathrm{C}\right)$, their altitudes on southern slopes were higher than on northern slopes. 
Table 3 Linear regression equations describing relations between altitude and decadal averages of annual air temperature depending on land form (concave, convex) and aspect (northern, southern)

\begin{tabular}{|c|c|c|c|c|}
\hline \multirow[t]{2}{*}{ Period } & \multicolumn{2}{|l|}{ Relief } & \multicolumn{2}{|l|}{ Aspect } \\
\hline & Concave & Convex & Northern & Southern \\
\hline 1951-1960 & $t=-0.0056 \mathrm{~h}+9.8$ & $t=-0.0053 \mathrm{~h}+10.0$ & $t=-0.0043 \mathrm{~h}+8.4$ & $t=-0.0046 \mathrm{~h}+9.3$ \\
\hline$R^{2}$ & 0.986 & 0.992 & 0.937 & 0.974 \\
\hline $\mathrm{T} 1000 \mathrm{~m}$ & $4.2^{\circ} \mathrm{C}$ & $4.8^{\circ} \mathrm{C}$ & $4.1^{\circ} \mathrm{C}$ & $4.7^{\circ} \mathrm{C}$ \\
\hline $\mathrm{T} 1500 \mathrm{~m}$ & $1.4^{\circ} \mathrm{C}$ & $2.1^{\circ} \mathrm{C}$ & $2.0^{\circ} \mathrm{C}$ & $2.4^{\circ} \mathrm{C}$ \\
\hline 1981-1990 & $t=-0.0065 \mathrm{~h}+10.7$ & $t=-0.0051 \mathrm{~h}+10.0$ & $t=-0.0042 \mathrm{~h}+8.3$ & $t=-0.0040 \mathrm{~h}+8.9$ \\
\hline$R^{2}$ & 0.988 & 0.979 & 0.936 & 0.994 \\
\hline $\mathrm{T} 1000 \mathrm{~m}$ & $4.2^{\circ} \mathrm{C}$ & $4.9^{\circ} \mathrm{C}$ & $4.1^{\circ} \mathrm{C}$ & $5.0^{\circ} \mathrm{C}$ \\
\hline $\mathrm{T} 1500 \mathrm{~m}$ & $0.9^{\circ} \mathrm{C}$ & $2.4^{\circ} \mathrm{C}$ & $2.0^{\circ} \mathrm{C}$ & $3.0^{\circ} \mathrm{C}$ \\
\hline 1991-2000 & $t=-0.0073 \mathrm{~h}+11.5$ & $\mathrm{t}=-0.0051 \mathrm{~h}+10.1$ & $\mathrm{t}=-0.0042 \mathrm{~h}+8.4$ & $t=-0.0044 \mathrm{~h}+9.5$ \\
\hline$R^{2}$ & 0.998 & 0.994 & 0.881 & 0.976 \\
\hline $\mathrm{T} 1000 \mathrm{~m}$ & $4.2^{\circ} \mathrm{C}$ & $5.0^{\circ} \mathrm{C}$ & $4.2^{\circ} \mathrm{C}$ & $5.1^{\circ} \mathrm{C}$ \\
\hline $\mathrm{T} 1500 \mathrm{~m}$ & $0.6^{\circ} \mathrm{C}$ & $2.5^{\circ} \mathrm{C}$ & $2.1^{\circ} \mathrm{C}$ & $2.9^{\circ} \mathrm{C}$ \\
\hline 2001-2010 & $t=-0.0075 \mathrm{~h}+12.1$ & $t=-0.0051 \mathrm{~h}+10.5$ & $t=-0.0041 \mathrm{~h}+8.6$ & $\mathrm{t}=-0.0043 \mathrm{~h}+9.8$ \\
\hline$R^{2}$ & 0.994 & 0.993 & 0.8785 & 0.972 \\
\hline $\mathrm{T} 1000 \mathrm{~m}$ & $4.6^{\circ} \mathrm{C}$ & $5.4^{\circ} \mathrm{C}$ & $4.5^{\circ} \mathrm{C}$ & $5.5^{\circ} \mathrm{C}$ \\
\hline $\mathrm{T} 1500 \mathrm{~m}$ & $0.9^{\circ} \mathrm{C}$ & $2.8^{\circ} \mathrm{C}$ & $2.5^{\circ} \mathrm{C}$ & $3.4^{\circ} \mathrm{C}$ \\
\hline
\end{tabular}

$R^{2}$ coefficient of determination, $T 1000 \mathrm{~m}$ decadal air temperature at the altitude of $1000 \mathrm{~m}$ a.s.1., $T 1500 \mathrm{~m}$ decadal air temperature at the altitude of $1500 \mathrm{~m}$ a.s.l.

Table 4 Differences between decadal averages of annual air temperature from measurements and air temperature calculated from linear regression equations for decades: 1951-1960 (A), 1981-1990 (B), 1991-2000 (C), 2001-2010 (D)

\begin{tabular}{|c|c|c|c|c|c|c|c|c|c|c|c|c|c|c|c|c|c|}
\hline \multirow[t]{2}{*}{ Lp. } & \multirow[t]{2}{*}{ Station } & \multicolumn{4}{|c|}{ Northern aspect } & \multicolumn{4}{|c|}{ Southern aspect } & \multicolumn{4}{|c|}{ Concave land forms } & \multicolumn{4}{|c|}{ Convex land forms } \\
\hline & & A & $\mathrm{B}$ & $\mathrm{C}$ & $\mathrm{D}$ & A & $\mathrm{B}$ & $\mathrm{C}$ & $\mathrm{D}$ & A & $\mathrm{B}$ & $\mathrm{C}$ & $\mathrm{D}$ & A & B & $\mathrm{C}$ & $\mathrm{D}$ \\
\hline 1 & Červený Kláštor & - & 0.2 & 0.2 & 0.2 & . & . & . & . & . & . & . & . & . & . & . & . \\
\hline 2 & Maniowy & 0.4 & . & . & . & . & . & . & . & . & . & . & . & . & . & . & . \\
\hline 3 & Liptovský Mikuláš & . & . & . & . & -0.3 & -0.1 & -0.2 & 0.0 & . & . & . & . & . & . & . & . \\
\hline 4 & Ústie n. priehradou & -0.4 & - & - & - & . & - & - & - & . & - & - & - & . & - & - & - \\
\hline 5 & Liptovský Hrádok & . & . & . & . & 0.1 & -0.1 & -0.2 & -0.3 & 0.0 & 0.0 & -0.1 & -0.1 & . & . & . & . \\
\hline 6 & Poprad-Tatry & . & . & . & . & . & . & . & . & 0.2 & 0.1 & 0.1 & 0.1 & . & . & . & . \\
\hline 7 & Stará Lesná & - & . & . & . & - & 0.1 & 0.3 & 0.4 & - & . & . & . & - & 0.3 & 0.4 & 0.3 \\
\hline 8 & Tatranská Lomnica & . & . & . & . & . & . & . & . & -0.1 & -0.2 & 0.0 & 0.0 & . & . & . & . \\
\hline 9 & Witów & 0.0 & -0.4 & -0.6 & -0.4 & . & . & . & . & . & . & . & . & . & . & . & . \\
\hline 10 & Podbanské & . & . & . & . & 0.2 & 0.1 & -0.1 & -0.1 & . & . & . & . & 0.3 & 0.1 & -0.2 & -0.3 \\
\hline 11 & Tatranská Javorina & -0.1 & 0.2 & 0.1 & 0.3 & . & . & . & . & -0.1 & 0.1 & 0.0 & 0.1 & . & . & . & . \\
\hline 12 & Hala Ornak & 0.3 & 0.2 & 0.3 & 0.3 & . & . & . & . & 0.2 & -0.1 & 0.0 & -0.1 & . & . & . & . \\
\hline 13 & P. Chochołowska & - & - & - & . & - & - & - & 0.0 & - & - & - & . & - & - & - & . \\
\hline 14 & Štrbské Pleso & . & . & . & . & -0.3 & -0.3 & 0.5 & 0.1 & . & . & . & . & -0.5 & -0.7 & 0.1 & -0.3 \\
\hline 15 & Morskie Oko & . & . & . & . & 0.4 & - & - & - & . & . & . & . & . & . & . & . \\
\hline 16 & Hala Gąsienicowa & . & . & . & . & . & . & . & . & . & . & . & . & -0.4 & -0.2 & -0.4 & -0.3 \\
\hline 17 & Dolina 5 Stawów & . & . & . & . & 0.4 & -0.1 & 0.3 & 0.4 & . & . & . & . & 0.0 & -0.8 & -0.3 & -0.3 \\
\hline 18 & Skalnaté Pleso & . & . & . & . & -0.5 & -0.1 & -0.5 & -0.5 & . & . & . & . & . & . & . & . \\
\hline 19 & Kasprowy Wierch & . & . & . & . & . & . & . & . & . & . & . & . & 0.3 & 0.5 & 0.3 & 0.3 \\
\hline 20 & Lomnicky Štit & . & . & . & . & . & . & . & . & . & . & . & . & -0.1 & 0.3 & 0.0 & 0.0 \\
\hline
\end{tabular}

“_” lack of data, “.” not used 
Table 5 Mean absolute error (MAE) and root mean square error (RMSE) of estimation of annual air temperature by altitude as a predictor in linear regression for the Tatra Mountains

\begin{tabular}{|c|c|c|c|c|c|c|c|c|}
\hline \multirow[t]{3}{*}{ Period } & \multicolumn{4}{|c|}{ Aspect } & \multicolumn{4}{|l|}{ Relief } \\
\hline & \multicolumn{2}{|c|}{ Northern } & \multicolumn{2}{|c|}{ Southern } & \multicolumn{2}{|c|}{ Concave } & \multicolumn{2}{|c|}{ Convex } \\
\hline & MAE & RMSE & MAE & RMSE & MAE & RMSE & MAE & RMSE \\
\hline 1951-1960 & 0.025 & 0.186 & 0.319 & 0.668 & 0.091 & 0.389 & 0.273 & 0.640 \\
\hline 1981-1990 & 0.058 & 0.294 & 0.118 & 0.407 & 0.101 & 0.411 & 0.414 & 0.761 \\
\hline 1991-2000 & 0.017 & 0.158 & 0.267 & 0.596 & 0.046 & 0.277 & 0.232 & 0.570 \\
\hline 2001-2010 & 0.028 & 0.206 & 0.239 & 0.564 & 0.093 & 0.393 & 0.261 & 0.605 \\
\hline
\end{tabular}

The minor differences in the location of the $-2{ }^{\circ} \mathrm{C}$ isotherm between $\mathrm{S}$ and $\mathrm{N}$ slopes are due to the secondary relevance of aspects at the highest elevations. The rate of changes varies depending on the isotherm. The most spectacular shift took place in the lowest part of the Tatra Mountains on southern slopes, where the $+6{ }^{\circ} \mathrm{C}$ isotherm moved up $163 \mathrm{~m}$ in terms of altitude between 1951-1960 and 2001-2010. This isotherm on $\mathrm{N}$ slopes lay far outside the research area and therefore could not be examined with respect to changes. The border between the moderately cool and cool $\left(+4{ }^{\circ} \mathrm{C}\right)$ belts rose by $120 \mathrm{~m}$ on northern slopes and by $131 \mathrm{~m}$ on southern slopes. The relocation of the $+2{ }^{\circ} \mathrm{C}$ isotherm involved the shortest distances,
Fig. 8 Vertical climatic belts in the Tatra Mountains and surroundings in the 1951-1960 (upper map, a) and 2001-2010 (lower map, b) decades

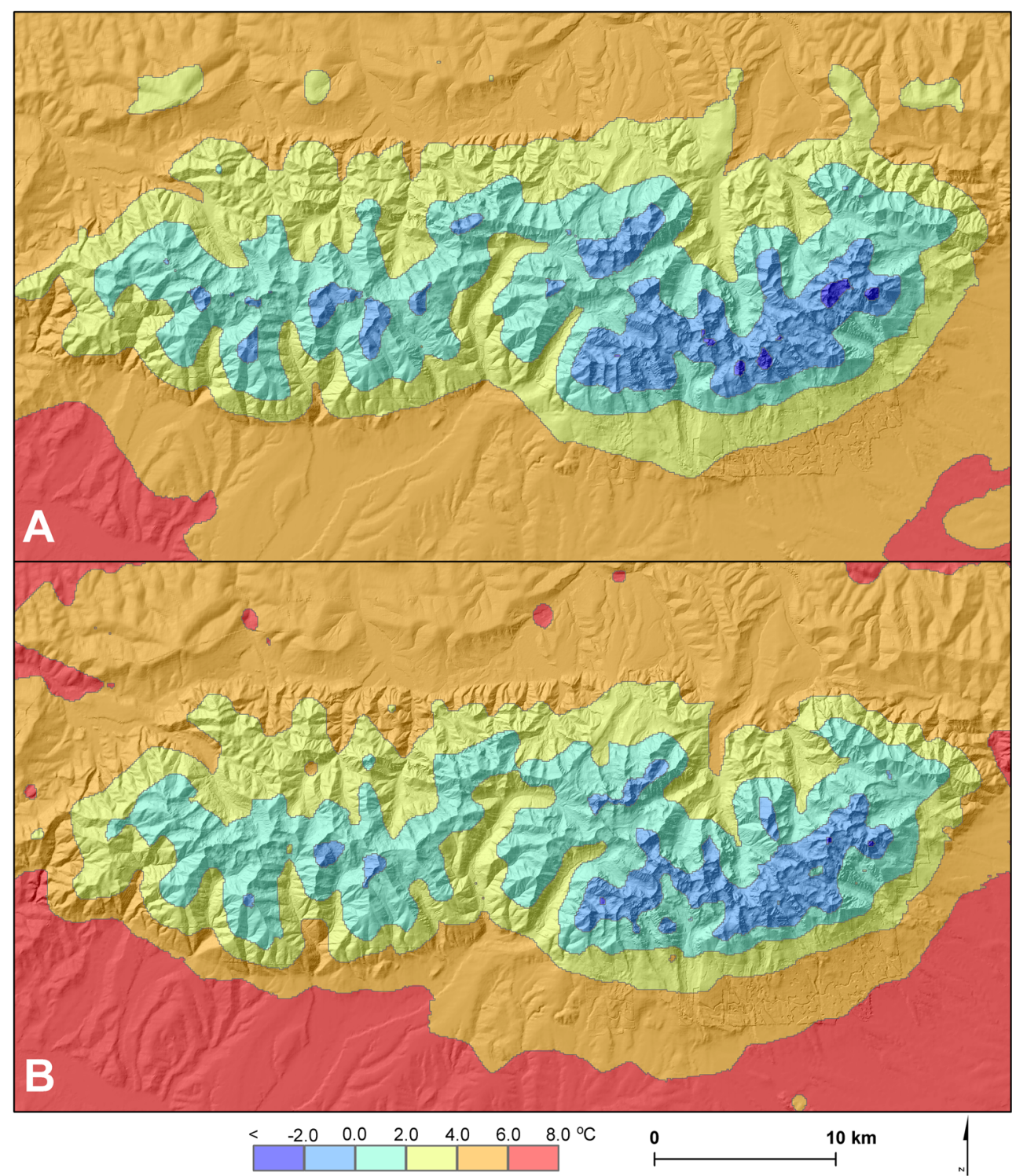


Table 6 Planar areas of the vertical climatic belts in the Tatra Mountains

\begin{tabular}{|c|c|c|c|c|c|c|c|c|c|c|c|c|}
\hline \multirow[t]{2}{*}{ Decades } & \multicolumn{2}{|c|}{$<-2{ }^{\circ} \mathrm{C}$} & \multicolumn{2}{|c|}{-2 to $0{ }^{\circ} \mathrm{C}$} & \multicolumn{2}{|c|}{0 to $2{ }^{\circ} \mathrm{C}$} & \multicolumn{2}{|c|}{2 to $4{ }^{\circ} \mathrm{C}$} & \multicolumn{2}{|c|}{4 to $6{ }^{\circ} \mathrm{C}$} & \multicolumn{2}{|l|}{$>6^{\circ} \mathrm{C}$} \\
\hline & $\mathrm{km}^{2}$ & $\%$ & $\mathrm{~km}^{2}$ & $\%$ & $\mathrm{~km}^{2}$ & $\%$ & $\mathrm{~km}^{2}$ & $\%$ & $\mathrm{~km}^{2}$ & $\%$ & $\mathrm{~km}^{2}$ & $\%$ \\
\hline (a) 1951-1961 & 3.4 & 0.2 & 93.4 & 5.6 & 270.6 & 16.1 & 367.7 & 21.9 & 861.4 & 51.2 & 84.7 & 5.0 \\
\hline (b) 1981-1991 & 0.8 & 0.0 & 78.9 & 4.7 & 274.7 & 16.3 & 344.6 & 20.5 & 871.5 & 51.8 & 110.7 & 6.6 \\
\hline (c) 1991-2001 & 1.4 & 0.1 & 83.5 & 5.0 & 274.7 & 16.3 & 322.0 & 19.2 & 781.8 & 46.5 & 217.8 & 13.0 \\
\hline (d) 2001-2010 & 0.2 & 0.0 & 57.8 & 3.4 & 249.4 & 14.8 & 292.4 & 17.4 & 714.1 & 42.5 & 367.2 & 21.8 \\
\hline $\mathrm{b}-\mathrm{a}$ & -2.6 & -0.2 & -14.5 & -0.9 & +4.1 & +0.2 & -23.8 & -1.4 & +10.1 & +0.6 & +26.0 & +1.6 \\
\hline$c-b$ & +0.6 & +0.1 & +4.6 & +0.3 & 0.0 & 0.0 & -22.6 & -1.3 & -89.7 & -5.3 & +107.1 & +6.4 \\
\hline d-c & -1.2 & -0.1 & -25.7 & -1.6 & -25.3 & -1.5 & -29.9 & -1.8 & -67.7 & -4.0 & +149.4 & +8.8 \\
\hline$d-b$ & -0.6 & 0.0 & -21.1 & -1.3 & -25.3 & -1.5 & -52.5 & -3.1 & -157.4 & -9.3 & +256.5 & +15.7 \\
\hline $\mathrm{d}-\mathrm{a}$ & -3.2 & -0.2 & -35.6 & -2.2 & -21.2 & -1.3 & -75.3 & -4.5 & -147.3 & -8.7 & -282.5 & +16.8 \\
\hline
\end{tabular}
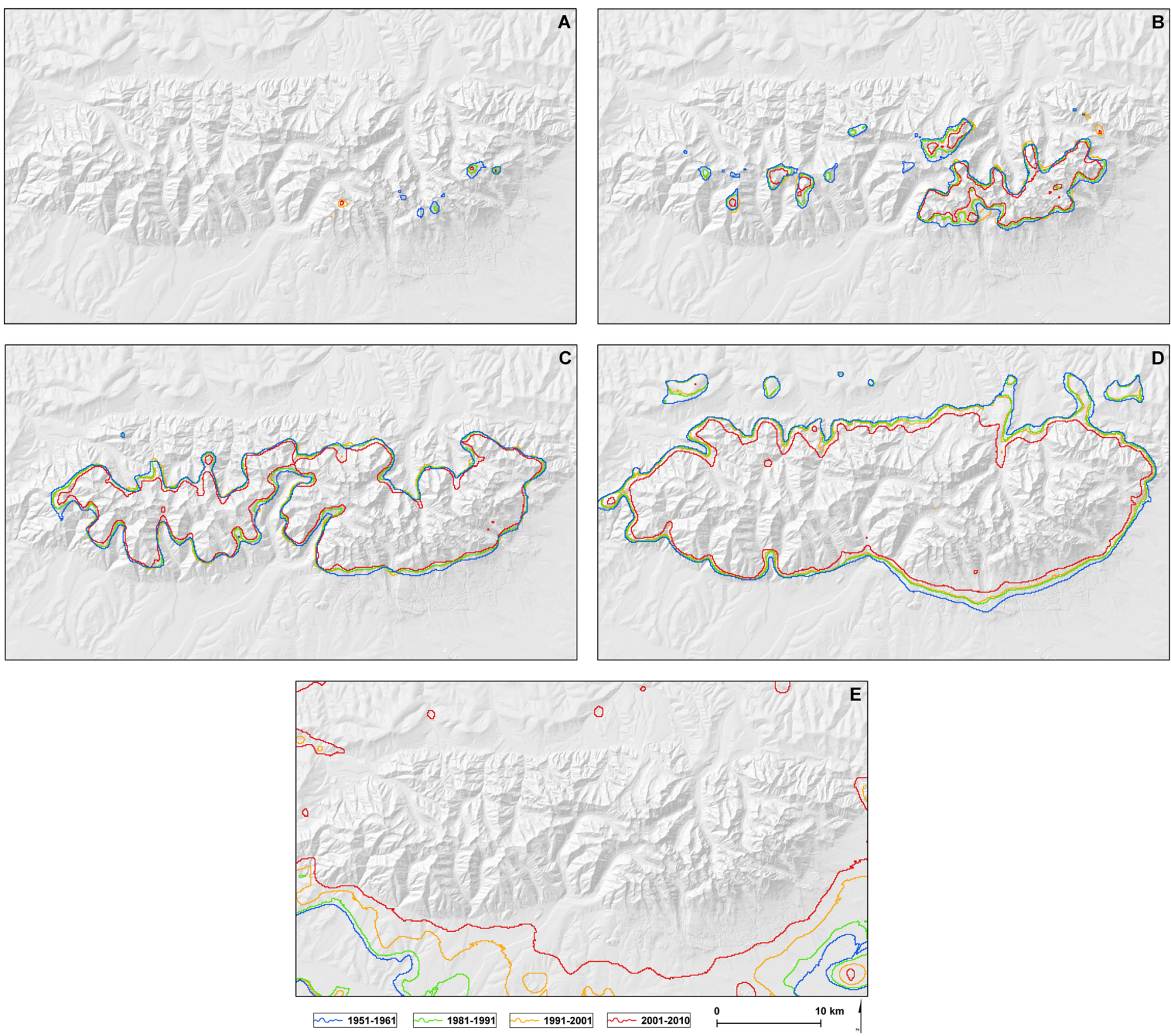

Fig. 9 Temporal changes in the location of borders (threshold isotherms) between vertical climatic belts in the Tatra Mountains: $\mathbf{a}-2{ }^{\circ} \mathrm{C}, \mathbf{b} 0{ }^{\circ} \mathrm{C}, \mathbf{c}+$ $2{ }^{\circ} \mathrm{C}, \mathbf{d}+4{ }^{\circ} \mathrm{C}$, and $\mathbf{e}:+6{ }^{\circ} \mathrm{C}$ 
which indicates that in the Tatra Mountains the smallest changes took place at altitudes of 1453-1531 m a.s.l. on N and 1517$1622 \mathrm{~m}$ a.s.l. on $\mathrm{S}$ slopes. The isotherm of $0^{\circ} \mathrm{C}$, which is the upper limit of the subalpine belt, changed altitude by +105 on southern and by $+35 \mathrm{~m}$ a.s.l. on northern slopes, representing the greatest differences in the rate of changes depending on aspect. The boundary of the highest belt, with an annual air temperature below $-2{ }^{\circ} \mathrm{C}$, was elevated by $109 \mathrm{~m}$ on $\mathrm{N}$ and by $214 \mathrm{~m}$ on S slopes (Fig. 9, Tables 7 and 8 ).

\section{Discussion}

Zonation, the most characteristic feature of mountain areas, concerns climate, as well as other climate-related features and processes, including the type and intensity of certain morphogenetic processes, rock weathering, soil types, rates of soil-forming processes, types of plant ecosystems, and associated faunal species (Balon 1991; Guzik and Skawiński 2009). The configuration of climatic vertical belts in the Tatra Mountains was determined using a manual approach at the end of the 1960s and beginning of the 70s (Hess 1966, 1974). In the present paper, using the relationships between annual air temperature and altitude discovered by Hess (1966, 1974), as well as the Geographical Information System, we examined temporal changes in the configuration of the vertical climatic belts. The issue is particularly important due to the significant increase in annual air temperature that, as we found, started in the Tatra Mountains in the early 1980s. The rate of warming was various and independent of altitude. The increases in annual air temperature at the Zakopane station, representing the foothills of the Tatra Mountains, and at Kasprowy Wierch, located at a high altitude, are similar, which may suggest uniformity in the warming rate in the vertical profile. Homogenous warming at all altitude ranges was also found in the French Northern Alps (Dumas 2013). However, the pattern of warming depends on the region. In upland areas of other Alpine regions, warming was sometimes more marked at higher altitudes (Bücher and Dessens 1991; Weber et al. 1997; Gobiet et al. 2014).

Changes in air temperature in high mountain ecosystems is of utmost importance, because these ecosystems are controlled by low temperatures (Pauli et al. 2005) and are distinguished by strong altitudinal gradients (including air temperature) and minimal human impact (Graumlich 2000; Becker and Bugmann 2001; Graumlich et al. 2005). The combination of the relationship "altitude and annual air temperature" and GIS enabled us to model decadal air temperature for a dense set of points; this turned out to be very useful in the Tatra Mountains, where meteorological stations are scarce. Thus, changes in the distribution of the vertical climatic belts were identified using modelled data. As the data were modelled on the basis of station data, temporal changes in the modelled decadal air temperature refer strongly to the character of changes at the stations and probably do not incorporate some regional variations. On the other hand, the high correlation of annual air temperatures between stations (1981-2010) suggests that the identified shifts in the vertical climatic belts reflect general changes taking place in the Tatra Mountains.

Our results indicate that decadal averages of annual air temperature reflect fluctuation inherent in climate data, something that can be seen clearly when subsequent decades are compared. For example, despite general warming, at some stations the decade 1991-2000 turned out to be colder than the previous decade, 1981-1990. Regardless of such fluctuations, we found clear shifts in the vertical climatic belts. In a comparison of the earliest and the latest decades, these shifts were enhanced on southern slopes in comparison with northern slopes.
Table 7 The average, maximum, and minimum altitude [m a.s.l.] of borders (threshold isotherms) between vertical climatic belts in the Tatra Mountains on northern $(\mathrm{N})$ and southern $(\mathrm{S})$ slopes

\begin{tabular}{|c|c|c|c|c|c|c|c|c|c|c|c|}
\hline \multirow[t]{2}{*}{ Decades } & \multirow[t]{2}{*}{$\mathrm{H}$} & \multicolumn{2}{|c|}{$-2{ }^{\circ} \mathrm{C}$} & \multicolumn{2}{|l|}{$0{ }^{\circ} \mathrm{C}$} & \multicolumn{2}{|l|}{$2^{\circ} \mathrm{C}$} & \multicolumn{2}{|l|}{$4^{\circ} \mathrm{C}$} & \multicolumn{2}{|c|}{$6{ }^{\circ} \mathrm{C}$} \\
\hline & & $\mathrm{N}$ & S & $\mathrm{N}$ & $\mathrm{S}$ & $\mathrm{N}$ & $\mathrm{S}$ & $\mathrm{N}$ & $\mathrm{S}$ & $\mathrm{N}$ & $\mathrm{S}$ \\
\hline \multirow[t]{3}{*}{ 1951-1961 } & Avg. & 2342 & 2237 & 1893 & 1945 & 1455 & 1518 & 1043 & 1128 & 736 & 707 \\
\hline & Max & 2547 & 2491 & 2150 & 2205 & 1657 & 1746 & 1174 & 1312 & 754 & 780 \\
\hline & Min & 2069 & 2073 & 1581 & 1680 & 1262 & 1269 & 900 & 978 & 715 & 664 \\
\hline \multirow[t]{3}{*}{ 1981-1991 } & Avg. & 2374 & 2507 & 1885 & 1994 & 1459 & 1574 & 1069 & 1179 & 707 & 724 \\
\hline & Max & 2447 & 2593 & 2160 & 2228 & 1657 & 1807 & 1194 & 1541 & 750 & 789 \\
\hline & Min & 2288 & 2426 & 1606 & 1667 & 1262 & 1280 & 956 & 985 & 682 & 668 \\
\hline \multirow[t]{3}{*}{$1991-2000$} & Avg. & 2376 & 2497 & 1863 & 1949 & 1453 & 1569 & 1079 & 1196 & 679 & 795 \\
\hline & Max & 2497 & 2576 & 2150 & 2223 & 1702 & 1803 & 1212 & 1541 & 729 & 850 \\
\hline & Min & 2250 & 2417 & 1560 & 1564 & 1249 & 1300 & 956 & 997 & 626 & 718 \\
\hline \multirow[t]{3}{*}{ 2001-2010 } & Avg. & 2451 & 2451 & 1928 & 2050 & 1531 & 1622 & 1162 & 1259 & 755 & 870 \\
\hline & Max & & & 2218 & 2344 & 1761 & 1978 & 1377 & 1566 & 912 & 966 \\
\hline & Min & - & - & 1665 & 1647 & 1240 & 1305 & 1017 & 1029 & 670 & 748 \\
\hline
\end{tabular}

$H$ altitude, $A v g$. average, Max maximum, Min minimum, $N$ northern slopes, $S$ southern slopes 
Table 8 Differences [m above sea level] between the average altitude of borders (threshold isotherms) between vertical climatic belts in the Tatra Mountains

\begin{tabular}{|c|c|c|c|c|c|c|c|c|c|c|}
\hline \multirow[t]{2}{*}{ Decades } & \multicolumn{2}{|l|}{$-2{ }^{\circ} \mathrm{C}$} & \multicolumn{2}{|l|}{$0{ }^{\circ} \mathrm{C}$} & \multicolumn{2}{|l|}{$2{ }^{\circ} \mathrm{C}$} & \multicolumn{2}{|l|}{$4^{\circ} \mathrm{C}$} & \multicolumn{2}{|l|}{$6^{\circ} \mathrm{C}$} \\
\hline & $\mathrm{N}$ & $\mathrm{S}$ & $\mathrm{N}$ & $\mathrm{S}$ & $\mathrm{N}$ & $\mathrm{S}$ & $\mathrm{N}$ & $\mathrm{S}$ & $\mathrm{N}$ & $\mathrm{S}$ \\
\hline 2001/2010-1991/2000 & +75 & +46 & +65 & +101 & +79 & +54 & +83 & +63 & +76 & +75 \\
\hline 2001/2010-1981/1990 & +77 & -56 & +43 & +56 & +72 & +48 & +93 & +80 & +48 & +146 \\
\hline 2001/2010-1951/1960 & +109 & +214 & +35 & +105 & +76 & +105 & +120 & +131 & +19 & +163 \\
\hline
\end{tabular}

Importantly, in the past decade (2001-2010), the highest cold belt virtually disappeared. However, this effect may not be permanent. The cold belt may expand in future, provided that decadal air temperature decreases. Nonetheless, climate modelling studies predict future warming (IPCC 2013); therefore, changes in the locations and extents of the vertical climatic belts may continue in the future; if so, they will probably affect climate-related features of the environment. A complete disappearance of the very cool belt in the Karkonosze Mountains (Poland) caused by an increase in the air temperature of $1 \mathrm{~K}$ was predicted by Migała (2005). Kożuchowski (1996) estimated that an increase of 4-5 $\mathrm{K}$ in annual air temperature and of $2 \mathrm{~K}$ in the air temperature of the warmest month would cause an upward shift of about 300 to $360 \mathrm{~m}$ in the locations of the vertical climatic belts in the Tatra Mountains. The rate of shifts measured by Kożuchowski (1996) above the $0{ }^{\circ} \mathrm{C}$ isotherm is greater than that in the lower parts of the Tatra Mountains; this finding is in agreement with our calculations.

According to the European Environment Agency (EEA 2009), the observed and projected impacts of climate change on mountain environments include uphill distribution shifts on the part of many European plant species; $60 \%$ of mountain plant species may face extinction by 2100 . The loss of the coldest climatic zones on mountain peaks, general upslope shifts of vegetation belts, and loss of biodiversity are the effects of climate impacts mentioned most often (e.g. Puhe and Urlich 2001; Gottfried et al. 2002; Beniston 2006; Spehn and Körner 2005). It has been predicted that for each $1 \mathrm{~K}$ of warming, vertical climatic belts may be shifted upward by $150 \mathrm{~m}$ or more (Grace 1989). Climate impact research conducted in selected Alpine environments showed that mountain plants migrated upward during the twentieth century due to increases in air temperature (Grabherr et al. 1994, 1995, 2001; Pauli et al. 1996, 2001, 2005). In the subalpine turfless zones of the Sudetens and the Alps, an increase in the biodiversity of vascular plants was accompanied by a reduction in the number of endemic and rare species (Wojtun et al. 1995). Moreover, Huntley (1991) suggested that three responses are possible at species level: genetic adaptations, biological invasions through species inter-comparison, and species extinction. Progressive replacement of currently dominant species by more thermophilous species (Grabherr et al. 1994; Keller et al. 2000) and declines in extreme high-altitude species at their lower range margins have already been observed in the European Alps (Gottfried et al. 2002, 2012).

The response of ecosystems in mountain regions is expected to be the most significant at ecolines or ecotones. The most visible ecological boundary is the timberline. However, the relocation of timberlines as an effect of climate change will not be rapid due to their longevity and may even take centuries (Ives and Hansen-Bristow 1983). Another problem is human-induced changes (e.g. pastoral activity, felling) at timberline altitudes, which may mask potential changes resulting from climate change. In the Tatra Mountains, ca $33 \%$ of the length of the timberline is located at its natural altitude (between 1264 and $1650 \mathrm{~m}$ a.s.1.) while ca $67 \%$ has been artificially lowered - in extreme cases, by as much as $140 \mathrm{~m}$ (Fabijanowski 1962). On the other hand, due to the abovementioned land-use changes, large-scale relocation processes are probable over the next decades even in stable climatic conditions (Tinner and Ammann 2005). For example in Poland, at Babia Góra (1750 m a.s.l., Beskid Żywiecki), about 1/3 of the length of the timberline has been elevated over the past 45 years, mostly due to the cessation of anthropopression in the 1920s and 1930s. However, two overlapping factors were found to cause this effect: reduced human pressure and present climate changes (Czajka and Kaczka 2014). According to Bugmann and Pfister (2000), the areas between the morphological and climatic timberlines are the most sensitive to climate change.

Animals will probably respond to climate change much faster than plants, as a result of their mobility, ability to adapt, and shorter life cycles (Ozenda and Borel 1990; Puhe and Urlich 2001). To date, no research on plant response to climate change has been conducted in the Tatra Mountains. Although every mountain range is unique, the potential consequences of changes in vertical climatic belts might be analogous to those in other mountains, particularly in central Europe.

\section{Conclusions}

Using the relationships between altitude and decadal air temperature as well as Geographical Information Systems, we analysed temporal changes in the extent and location of vertical climatic zones in the Tatra Mountains, where 
meteorological stations are scarce. Four decades representing various phases of climate change were compared (1951-1960, 1981-1990, 1991-2000, and 2001-2010). The earliest decade (1951-1960) represents a period of stable climate conditions, whereas the latest (2001-2010) covers a period of rapid increase in air temperature. Data from 20 meteorological stations were used to calculate regression equations describing the dependence of decadal air temperature on altitude separately for northern and southern slopes and for convex and concave landforms. Trends in annual air temperature in 1951-2016 at the Zakopane and Kasprowy Wierch stations were also discussed as a background for further analysis.

The key conclusions arising from this paper are as follows:

- A significant increase in annual air temperature at a rate of $0.5 \mathrm{~K}$ per decade started in the Tatra Mountains at the beginning of the 1980 s.

- Both the spatial extents and locations of the vertical climatic belts have changed over the research period; however, these changes have not been uniform.

- The most significant shifts have taken place at the lowest and at the highest altitudes.

- The area of the lowest belt has expanded, while the area of the vertical climatic belts above the snow line has diminished considerably. The smallest changes in area have been those affecting the very cool belt.

- The cold climatic belt, delineated by annual air temperatures lower than $-2{ }^{\circ} \mathrm{C}$, virtually disappeared during the research period. In the past decade, the cold climate belt occupied small areas on the highest peaks of the High Tatra Mountains.

- The uphill shift of the vertical climatic zones on southern slopes was greater than on northern slopes.

Acknowledgements We thank Tadeusz Niedźwiedź for his supportive comments on the manuscript. We express our special thanks to Pavel Št'astnỳ from the Slovak Hydrometeorological Institute for providing metadata on Slovak meteorological stations. Supportive comments by an anonymous reviewer are also appreciated.

Open Access This article is distributed under the terms of the Creative Commons Attribution 4.0 International License (http:// creativecommons.org/licenses/by/4.0/), which permits unrestricted use, distribution, and reproduction in any medium, provided you give appropriate credit to the original author(s) and the source, provide a link to the Creative Commons license, and indicate if changes were made.

\section{References}

Balon J (1991) Piętrowość w środowisku przyrodniczym Tatr (Altitudinal zonation in the environment of the Tatra Mountains). Czasopismo Geogr 62(4):283-298

Becker A, Bugmann H(2001) Global change and mountain regions: the mountain research initiative. In "Implementation Plan," IGBP report 49 / IHDP report 13/ GTOS report 28, Stockholm
Beniston M (2006) Mountain weather and climate: a general overview and a focus on climatic change in the alps. Hydrobiologia 562:3-16. https://doi.org/10.1007/s10750-005-1802-0

Beniston M, Diaz HF, Bradley RS (1997) Climatic change at high elevation sites: an overview. Clim Chang 36:233-251. https://doi.org/10. 1023/A:1005380714349

Bücher A, Dessens J (1991) Secular trend of surface temperature at an elevated observatory in the Pyrenees. J Clim 4:859-868. https://doi. org/10.1175/1520-0442(1991)004<0859:STOSTA >2.0.CO;2

Bugmann H, Pfister C (2000) Impacts of interannual climate variability on past and future forest composition. Reg Environ Chang 1(3-4): 112-125. https://doi.org/10.1007/s101130000015

Czajka B, Kaczka RJ (2014) Dendrochronologiczna charakterystyka górnej granicy lasu na Babiej Górze w strefie jej progresu (Dendrochronological characteristics of the timberline on Babia Mountain within the zone of its progress). Studia i Materiały CEPL w Rogowie R. 16. Zeszyt 40(3):42-52

Dumas D (2013) Changes in temperature and temperature gradients in the French Northern Alps during the last century. Theor Appl Climatol 111:223-233. https://doi.org/10.1007/s00704-012-0659-1

EEA (2009) Regional climate change and adaptation. The Alps facing the challenge of changing water resources. EEA (European Environment Agency) Report No 8/2009, ISSN 1725-9177, p:148

ESRI (Environmental Systems Research Institute) (2016) ArcGIS desktop: release 10.5. Redlands, California

Fabijanowski J (1962) Lasy Tatrzańskie (Forest of the Tatra Mountains). In: Szafer W, Tatrzański Park Narodowy. Polska Akademia Nauk, Zakład Ochrony Przyrody. Wydawnictwo Popularnonaukowe 21:240-304

Gobiet A, Kotlarski S, Beniston M, Heinrich G, Rajczak J, Stoffel M (2014) 21st century climate change in the European Alps - a review. Sci Total Environ 493:1138-1151. https://doi.org/10.1016/j. scitotenv.2013.07.050

Gottfried M, Pauli H, Futschik A, Akhalkatsi M, Barančok P, Alonso JLB, Coldea G, Dick J, Erschbamer B, Calzado MRF, Kazakis G, Krajči J, Larsson P, Mallaun M, Michelsen O, Moiseev D, Moiseev P, Molau U, Merzouki A, Nagy L, Nakhutsrishvili G, Pedersen B, Pelino G, Puscas M, Rossi G, Stanisci A, Theurillat J-P, Tomaselli M, Villar L, Vittoz P, Vogiatzakis I, Grabherr G (2012) Continentwide response of mountain vegetation to climate change. Nat Clim Chang 2:111-115

Gottfried M, Pauli H, Reiter K, Grabherr G (2002) Potential effects of climate change on alpine and nival plants in the Alps. In: Komer C, Spehn EM (eds) Mountain biodiversity: a global assessment. Parthenon, London, pp 215-226

Grabherr G, Gottfried M, Gruber A, Pauli H (1995) Patterns and current changes in alpine plant diversity. In: Chapin FS III, Komer C (eds) Arctic and alpine biodiversity: patterns, causes and ecosystem consequences. Springer, Berlin, pp 167-181. Ecological studies. https:// doi.org/10.1007/978-3-642-78966-3_12

Grabherr G, Gottfried M, Pauli H (1994) Climate effects on mountain plants. Nature 369:448. https://doi.org/10.1038/369448a0

Grabherr G, Gottfried M, Pauli H (2001) Long-term monitoring of mountain peaks in the Alps. In: Burga CA, Kratochwil A (eds) Biomonitoring: general and applied aspects on regional and global scales. Kluwer, Dordrecht, pp 153-177. Tasks for vegetation science

Grace J (1989) Tree lines. Philos Trans R Soc Lond B 324:233-245

Graumlich LJ (2000) Global change and wilderness areas: disentangling natural and anthropogenic changes. III Proceedings Wilderness Science in a Time of Change. Ogden, Utah, U.S. Department of Agriculture, Forest Service, Rocky Mountain Research Center

Graumlich LJ, Waggoner LA, Bunn AG (2005) Detecting global change at alpine treeline: coupling paleoecology with contemporary studies. In: Huber LJ, et al. (eds.) Global change and mountain regions: 501-508

Guzik M, Skawiński P (2009) Applying geomatics to determination of landscape altitudinal zones in the mountains. Landform Analysis 11:25-32 
Hess M (1965) Piętra klimatyczne w Polskich Karpatach Zachodnich (Vertical climatic belts in the Polish Western Carpathians). Zesz. Nauk. UJ CXV. Pr Geogr 11(33):1-268

Hess M (1966) O mezoklimacie wypukłych i wklesłych form terenowych w Polsce Południowej (On the mesoclimate of concave land forms in Southern Poland). Prz Geofizyczny 11 (19), 1:23-35

Hess M (1968) Metoda określania ilościowego zróżnicowania mezoklimatycznego w terenach górskich (A new method of quantitative determination of the mesoclimatic differentiation in mountain areas). Zeszyty Naukowe Uniwersytetu Jagiellońskiego CLXXIX. Prace Geogr Problemy Klimatologii Gór i Wyżyn 18(40):7-26

Hess M (1974) Piętra klimatyczne Tatr (vertical climatic belts in the Tatra Mountains). Czasopismo Geogr 45(1):75-95

Hess M, Niedźwiedź T, Obrębska-Starklowa B (1975) Przyczynek do metod konstruowania szczegółowych map klimatycznych terenów górskich i wyżynnych. (Contribution to the methods of construction of climatic maps of various scales for mountainous and upland territories). Zeszyty Naukowe Uniwersytetu Jagiellońskiego CCCCXIV. Pr Geogr. Problemy Klimatologii Gór i Wyżyn 41(63):7-35

Huntley B (1991) How plant respond to climate change: migration rates, individualism and the consequences for plant communities. Ann Bot 67:15-22

Iives JD, Hansen-Bristow KJ (1983) Stability and instability of natural and modified upper timberline landscapes in the Colorado Rocky Mountains, USA. Mt Res Dev 3:149-155

IMGW (1959-1965) Meteorological yearbooks. Institute of Meteorology and Water Management, Warszawa

IPCC (2013) Summary for policymakers. In: Stocker TF, Qin D, Plattner G-K, Tignor M, Allen SK, Boschung J, Nauels A, Xia Y, Bex V, Midgley PM (eds) Climate change 2013: the physical science basis. Contribution of working group I to the fifth assessment report of the intergovernmental panel on climate change. Cambridge University Press, Cambridge

Keller F, Kienast F, Beniston M (2000) Evidence of the response of vegetation to environmental change at high elevation sities in the Swiss alps. Reg Environ Chang 1(2):70-77. https://doi.org/10.1007/ PL00011535

Konček, M (1974) Klima Tatier (climate of the Tatras). Veda, Bratislava. $856 \mathrm{p}$ (in Slovak)

Kożuchowski K (1996) Vertical zones in the Tatra Mountains: contemporary arrangements and potential changes. Czasopismo Geogr 67(2):227-231

Lupikasza E, Niedzwiedz T, Pinskwar I, Ruiz-Villanueva V, Kundzewicz ZW (2016) Observed changes in temperature and precipitation and relationship between them, in the Upper Vistula Basin. In: Kundzewicz ZW, Stoffel M, Niedźwiedź T, Wyżga B (eds) Flood risk in the Upper Vistula Basin. Spinger, Cham

Migała K (2005) Piętra klimatyczne w górach Europy a problem zmian globalnych (Vertical climatic zones in the European Mountains against the problems of global changes). Acta Universitatis Wratislaviensis no 2718. Studia Geogr 78. Wydawnictwo Uniwersytetu Wrocławskiego

Niedźwiedź T (1992) Climate of the Tatra Mountains. Mt Res Dev 12(2): 131-146. https://doi.org/10.2307/3673787
Niedźwiedź T, Łupikasza E, Pińskwar I, Kundzewicz ZW, Stoffel M, Małarzewski $Ł$ (2015) Climatological background of floods at the northern foothills of the Tatra Mountains. Theor Appl Climatol 119: 273-284. https://doi.org/10.1007/s00704-014-1108-0

NMT (Numeryczny model terenu / Digital Elevation Model) (2014) GUGiK, License no DIO.DFT.DSI.7211.18428.2014_PL_N for University of Silesia in Katowice

Olecka A (1993) Climate change scenario for Poland based on GISS GSM. Global warming and contemporary climatic changes in Poland, Szczecin: 12

Ozenda P, Borel JL (1990) The possible responses of vegetation to a global climatic change. In: Boer MM, De Groot RS (eds) Landscapeecological impact of climatic change. IOS, Amsterdam, pp 221-249

Pauli H, Gottfried M, Grabherr G (1996) Effects of climate change on mountain ecosystems - upward shifting of alpine plants. World Resour Rev 8:382-390

Pauli H, Gottfried M, Grabherr G (2001) High summits of the Alps in a changing climate. The oldest observation series on high mountain plant diversity in Europe. In: Walther G-R, Burga CA, Edwards PJ (eds) Fingerprints of climate change: adapted behaviour and shifting species ranges. Kluwer, New York, pp 139-149

Pauli H, Gottfried M, Hohenwallner D, Reiter K, Grabherr G (2005) Ecological climate impact research in high mountain environments: GLORIA (global observation research initiative in alpine environments) - its roots, purpose and long-term perspectives. In: Huber LJ, et al. (eds) Global change and mountain regions: 383-391

Puhe J, Ulrich B (2001) Global climate change and human impacts on forest ecosystems postglacial development, present situation, and future trends in Central Europe. Ecological studies, vol 143. Springer-Verlag, Berlin, p 592

Spehn EM, Körner C (2005) A global assessment of mountain biodiversity and its function. In: Huber UM, et al. (eds) Global change and mountain regions, 393-400. doi:https://doi.org/10.1007/1-4020-3508-X_39

Tinner W, Ammann B (2005) Long-term responses of mountain ecosystems to environmental changes: resilience, adjustment, and vulnerability. In: Huber LJ, et al. (eds) Global change and mountain regions: $133-143$

Valor GB (2017) OGIMET — professional information about meteorological conditions in the world (SYNOP messages available on-line on the web site: http://www.ogimet.com). Last access 15 May 2015

Weber R, Talkner P, Auer I, Böhm R, Gajic-Capka M, Zaninovic K, Brádzil R, Faško $P$ (1997) 20th-century changes of temperature in the mountain regions of Central Europe. Clim Chang 36:327-344. https://doi.org/10.1023/A:1005378702066

Wojtuń B, Fabiszewski J, Sobierajski Z, Matuła J, Żołnierz L (1995) Współczesne przemiany wysokogórskich fitocenoz Karkonoszy (Contemporary changes in high mountain fitocenosis of the Karkonosze Mountains). In: Fischer Z (ed) Problemy ekologiczne wysokogórskiej części Karkonoszy. Oficyna Wyd. Inst. Ekologii PAN, Warszawa, pp 213-246

Żmudzka E (2009) Changes of thermal conditions in the Polish Tatra Mountains. Landform Anal 10:140-146

Żmudzka E (2011) Contemporary climate changes in the high mountain part of the Tatras. Pr Stud Geogr 2011(47):217-226. https://doi.org/ 10.2478/v10288-012-0005-6 